\title{
Rola elementów regionalnych w wybranych homiliach księdza Józefa Tischnera
}

We współczesnym polskim kaznodziejstwie i homiletyce zaznacza się wątek wypowiedzi z zastosowaniem gwar, co przybiera szczególną postać w przypadku gwary podhalańskiej. Takie realizacje wpisują się w odnowione zainteresowanie kulturą ludową, charakterystyczne dla lat dziewięćdziesiątych XX wieku. Świadczy o tym działalność Związku Podhalan oraz różnych ośrodków podejmujących ważną aktywność kulturową, by wymienić choćby edycje Festiwalu Ziem Górskich w Zakopanem czy imprezy Sabałowe Bajania oraz Karnawał Góralski w Bukowinie Tatrzańskiej, prowadzone pod kierownictwem dyrektorów Bukowiańskiego Centrum Kultury im. J. Pitoraka - Zygmunta Kuchty i Bartłomieja Koszarka, w których autor tego artykułu niejednokrotnie uczestniczył. Zadania kultywowania kultury ludowej podejmowały liczne zespoły oraz jednostki,

1 Ks. Marcin Godawa - doktor habilitowany, adiunkt z habilitacją w Papieskim Uniwersytecie Jana Pawła II w Krakowie. Zajmuje się badaniami nad medytacją chrześcijańską, duchowością tak staropolską, jak i współczesną, związkami teologii z retoryką i literaturą, szczególnie w ramach wpółpracy międzynarodowej. Autor m.in. publikacji Obraz Tajemnicy. Wcielenie i Narodzenie Pańskie w retorycznych medytacjach wybranych autorów środowiska krakowskiego w pierwszej połowie XVII wieku, Kraków 2015. E-mail: marcin.godawa@upjp2.edu.pl. 
powodując jej swoisty renesans. Ponieważ związek człowieka z kulturą ludową odznaczał się siłą autentycznego przeżywania, w sposób naturalny próbowano również połączyć tę kulturę i gwarę, jej znak szczególny, z dziedziną wiary i życia religijnego. Pochwała religijności góralskiej przez Jana Pawła II oraz symboliczny hołd górali polskich w czasie mszy świętej w Zakopanem w 1997 roku mogły stanowić uzasadnienie dla takich dzieł. Sprzyjała temu praca kapelanów Związku Podhalan, w tym ks. Władysława Zązla, ks. Tadeusza Juchasa czy ks. prof. Józefa Tischnera. W tym całym nurcie można umieścić przekład Nowego Testamentu na gwarę góralską, dokonany przez Marię Matejową-Torbiarz we współpracy z ks. Mirosławem Drozdkiem z sanktuarium na Krzeptówkach i ks. W. Zązlem². Przyjęty z różnymi ocenami stanowił znak przypominający w sposób szczególny o uwarunkowaniach i możliwych nadużyciach w tej dziedzinie. Napomnieniem wymierzonym w tę szeroko pojętą praktykę było pismo Pro memoria o tzw. Mszach Św. „w góralskiej oprawie” ks. kard. Stanisława Dziwisza z 2005 roku $^{3}$, którego celem było stosowne oczyszczenie relacji pomiędzy liturgią a kulturą ludową, z zachowaniem wartości także tej ostatniej.

Ksiądz Józef Tischner jest jednym z wybitnych przedstawicieli tego interesującego nurtu polskiej homiletyki. Szczególnym świadectwem mogą tu być jego homilie głoszone przez kilkanaście lat w czasie mszy świętych w kaplicy pod Turbaczem, najczęściej w pierwsze niedziele sierpnia. Mowy te zostały zebrane w książce Słowo o ślebodzie, wydanej w Krakowie w $2003 \mathrm{roku}^{4}$. Spośród nich przedmiotem uwagi w tym artykule staną się te z lat 1989-1997. Podjęciu tematyki związanej z nową sytuacją historyczną i społeczną towarzyszy tu bardzo świadome sięganie po gwarę i inne elementy kultury ludowej, aby wzmocnić w ten sposób proces inkulturacji Ewangelii, a patrząc z drugiej strony - proces duszpasterskiej perswazji. Gwara staje się bowiem bardzo ważnym narzędziem retorycznym.

2 Nowy Testament w przekładzie Marii Matejowej Torbiarz na gwarę górali skalnopodhalańskich z Zakopanego, red. M. Przybył, Zakopane 2005.

3 S. Dziwisz, Pro memoria o tzw. Mszach Św. „w góralskiej oprawie”, „Biuletyn Duszpasterski”, 12 (2005), s. 11-12.

4 J. Tischner, Słowo o ślebodzie. Kazania spod Turbacza 1981-1997, oprac. K. Tischner, posłowie W. Bonowicz, Kraków 2003. 
Zbadanie tych zależności stanowi cel poniższej pracy. Wyniki analizy zostaną przedstawione w trzech punktach, poczynając od kwestii różnorodnych zastosowań gwary w pogłębieniu kodu porozumienia poprzez podkreślenie szczególnie udanych realizacji z punktu widzenia retorycznego aż po ukazanie literatury gwarowej jako zbioru mi ejsc ws pólny ch, łączących mówcę i słuchaczy. Zarówno samo badanie, jak i pewne oceny podkreślają, że przepowiadanie w gwarze było ży w y m kształtowaniem interesującego modelu komunikacji.

\section{Gwara jako pogłębiony kod językowy w procesie perswazji}

Jeśli kluczową rzeczą w retoryce i homiletyce jest nawiązanie kontaktu mówcy ze słuchaczami, to Tischner osiąga ten cel w pogłębiony sposób, właśnie dzięki zastosowaniu elementów regionalnych. Świadczą o tym np. formuły powitania i figury zwrotu do zgromadzenia. Homileta w pierwszym z badanych tekstów używa zwrotu: „Bracia i siostry! Witojcie, ludzie gór!" (s. 73). Spotyka się tu element języka literackiego z powitaniem gwarowym, co sugeruje, że więźjest nie tylko liturgiczna i językowa, ale także regionalna, określana przez szczególny stosunek do gór, które funkcjonują tu zresztą jako metonimia kontekstu kulturowego. W dalszym ciągu autor używa chętnie inwokacji: ,ostomilsi”, niekiedy w połączeniu z zaimkiem „moi” (s. 85, 86, 93, 95, 98, 103, 110, 119, 120, 121, 122, $129,130,132)$, co sugeruje poczucie wspólnoty budowane także i w sposób szczególny na sile obyczaju ${ }^{5}$. Obok funkcji fatycznej formuła ta służy wprowadzeniu nowych elementów rozważania, np.: „Moi ostomilsi, taki jest głos serca zaklęty w góralskiej muzyce" (s. 85). W ten sposób znowu pozytywna treść inwokacji zyskuje rozszerzenie i wzmocnienie. W toku mowy słowo "ostomili” zostaje także użyte w celu przekonania do zmierzenia się ze sprawą, o której „nie słucho sie łatwo”. Homileta najpierw apeluje do poczucia godności słuchaczy: „Moi ostomilsi. Jako sie tu zbieromy, powinni my być dumni ze siebie" (s. 98). Dopiero po przypomnieniu

\footnotetext{
5 W homiliach rzadziej pojawia się także inwokacja: „moi drodzy” (por. s. 96, 121) czy „moi kochani” (por. s. 79).
} 
powodu dumy, tj. walki o wolność, zostaje wyeksponowana stająca przed audytorium konieczność wspólnego zorganizowanego działania, którego trudność polega na nowości takiej pracy. Podobna sekwencja pojawia się w zakończeniu, gdy mówca łączy z tą formułą retorycznie znaczącą pochwałę ich reakcji: „Wiym, moi ostomilsi, ze zawse to, co se tu pod Turbaczem co roku ukwolujemy, to zostaje we Wasyk sercak. I som sobie sie dziwiem, ze to mo takom siłe i ze tak zostaje" (s. 99). Odwołanie się do szlachetnego charakteru ${ }^{6}$ jest wzmocnione poprzez identyfikację gwarową, za którą oczywiście kryje się specyficzny i tak mocno podkreślany przez Tischnera etos, widoczny np. w pojęciu honoru. Taki sposób komunikacji można określić jako pogłębiony kod językowy, ponieważ gwara służy tu właśnie zbudowaniu głębszej więzi, podczas gdy do samego procesu komunikacji wystarczyłaby polszczyzna. Przytoczony przykład ukazuje także, jak elementy gwarowe, budując to poczucie jedności, spełniają funkcję perswazyjną, tworząc kanał, w którym przekaz trudnej prawdy staje się bardziej skuteczny.

W tym właśnie kodzie-ka nale perswazja przyjmuje formę gwarową bądź taką, w której polszczyzna wchodzi w interakcje z gwarą. Specyficznym sposobem wykorzystania słownictwa regionalnego jest operowanie czasownikami w trybie rozkazującym lub w bezokoliczniku traktowanym jako zadanie do wypełnienia. Na początku homilii z 6 sierpnia 1989 roku Tischner nazywa stan zgromadzenia słowem: „ześli [my sie]”, a następnie wyraża cel: „Przyśli my tu dziś poźryć na świat” (s. 73), by zaraz doprecyzować, na czym ma polegać właściwa postawa. „Poźryć” oznacza tutaj szerszy akt oglądu, właściwie rodzaj medytacji, w której podmiot spogląda z góry, by widzieć całość swych spraw. Do tego jednak konieczne jest milczenie: „Ostomilsi! Uciscie sie teroz, oddalcie od siebie syćkie niedobre myśli, zadumojcie sie nad światym, nad lasym, nad polanom, nad nasymi ludzkimi, ojcyźnianymi sprawami” (s. 73). Dumanie „nad polanom” staje się tu szczególnym sygnałem włączenia tego, co regionalne i codzienne w obręb rozważania. Nietrudno bowiem dostrzec, że „polana” pełni tu funkcję reprezentatywną jako synekdocha kultu-

6 Jest to także interesujący przykład potwierdzenia przez mówcę fortunności perlokucyjnej swego dzieła, choć oczywiście nie jest ono wolne od funkcji argumentacyjnych. 
$\mathrm{ry}^{7}$. Bardziej dobitnie wezwanie do zwrócenia się ku własnej kulturze zabrzmi w innej mowie: „Siednijcie na tom ziem, dotknijcie jom rękom. W tej ziemi jest trud wasyk ojców. Dotknijcie jom jesce roz - w tej ziemi jest krew ojców i dziadów, i braci" (s. 103). W doświadczenie pracy i historii, wyrażone słowami „trud" i „krew”, a więc w utrwalonym stylu wysokim, wprowadzają czasowniki „siednonć” i dwukrotne „dotknonć”, kontrastujące z poprzednimi efektem konkretności, która dzięki gwarze staje się bardziej dosadna. Podobnie na innym miejscu dotykanie ziemi ma wprowadzać w kontakt z tajemnicą miłości: „I tu roz jesce dotknijcie tej ziemi - tu jest prawo miłości" (s. 109). Tischner mówi jeszcze o niemożliwym zresztą do realizacji pragnieniu „namacania” wolności, czyli jej wyrazistego uchwycenia (por. s. 93). Konkretne czynności właściwe kulturze góralskiej, przywołane poprzez walory instrumentacyjne gwary opisują sposób działania, który jest drogą do tego, co bardziej abstrakcyjne, a jednocześnie stanowi eskpozycję zdroworozsądkowego podejścia do życia, „na chłopski rozum”, co pozwala zachować właściwy kierunek. Tu właśnie potrzebny jest kontrast. Mówiąc o sercu błądzącym, mówca przytacza anegdotę o turystach, którzy za pomocą mapy daremnie próbowali zrozumieć, gdzie się znajdują, i dopiero góral Zapała uświadomił im, że ta mapa w ogóle jest błędnie narysowana: „Panowie! Jakby tak wierzyć tymu papierowi, toście som hań" - i pokozoł na przeciwległy scyt" (s. 87). Kontynuacją tego antytetycznego, pańsko-góralskiego rozważania jest celna konkluzja: „Co robić, jakeś stracony? Moja rada prosto: siednij se. Siednij se - lepiyj ci wtedy siedzieć jako chodzić! Siedź a moze cie ludzie nojdom i powiedzom, ka tyn twój skarb jest" (s. 88). Proponowana tu postawa stanowi w sensie semantycznym i wartościującym przeciwieństwo działań, które człowiek byłby najbardziej skłonny podejmować. Powtarzane „siednij se” dzięki gwarowej intonacji tym bardziej podkreśla potrzebę nieszablonowego działania. Gdyby odwo-

7 Pod tym kątem warto byłoby prześledzić, jak ważne miejsce w kulturze i literaturze ludowej Podhala zajmuje polana. Jest ona przestrzenią uprawianą, ekonomiczną i w tym sensie przeciwstawia się dzikim górom. Jako miejsce łączy się z typem gazdy w przeciwieństwie do zbójnika, którego środowiskiem są surowe i niekultywowane przestrzenie górskie. Polana staje zatem miejscem kulturowym, na którym nie tylko wypasa się owce, ale i wznosi budynki. 
łać się do starszych tradycji, chociażby bajek ezopowych czy też poetyki konceptu, taką strategię można określić jako d ow c i p ną, bo negującą w sposób spektakularny przyjętą poważną formę.

Homilie spod Turbacza w intencji twórcy stanowić mają rodzaj rozważania, w którym konkret staje się drogą do abstrakcji. Ważne miejsce zajmują tu czasowniki i rzeczowniki opisujące takie właśnie działania. Można wymienić następujące formuły: „Bedziemy dziś ozwozać tą modlitwę” (s. 73); „Podumojmy jesce chwile” (s. 78); „o cymze nom trza dziś ozmyślać?”; „trza nom usłyseć głos serca. Rozumiycie? U sł y s e ć” (s. 84); „Serce suko serca” (s. 85); „trza tom prowde drązyć” (s. 86); „Niekze sie kozdy zadumie nad tom swojom wolnościom” (s. 95); „Posłuchajcie w zadumie” (s. 103); „ozwazanie nad sercem i nad skarbami” (s. 122). Wydaje się, że ta grupa określeń służy intencji przybliżenia duchowej tradycji Kościoła. Dla samego oddania czynności myślenia bardziej właściwe gwarze jest „dumanie” etc., natomiast słowa typu „ozwazanie” noszą w sobie ślad stosunkowo niedawnego importu z języka literackiego oraz z tradycji kościelnej, w której już np. w XVII wieku rozważanie miało znaczenie modlitwy myślnej ${ }^{8}$. Autor próbuje jednak pokonać dystans pomiędzy dziedziną kościelnej działalności a językiem codziennego doświadczenia. Czyni to jako kapłan i przewodniczący zgromadzenia liturgicznego z jednej, a góral i użytkownik gwary z drugiej strony.

W tym kontekście warto zwrócić uwagę na inne miejsca, w których na podobnej zasadzie przybliżane jest pojęcie bycia obywatelem. Należy zauważyć, że słowo to wchodzi w związki z elementami gwary, jednak samo nie przyjmuje formy gwarowej. Dzieje się tak zapewne dlatego, że struktura fonetyczna nie zostawia tu miejsca na taką transformację, z wyjątkiem nagłosowego „ł”. Tischner aplikuje do gwary formułę „wybijania się niewolnika na obywatela”, która należy do języka filozofii

8 Por. M. Godawa, Bogomyślność. Zagadnienie zjednoczenia człowieka z Bogiem w medytacji na podstawie Fascykułu nabożeństwa różnego Adama Opatowiusza, Kraków 2006, s. 19-23. Słownik Hodorowicza jako współczesne ujęcie podaje formę „ozwazować” (Słownik gwary górali Skalnego Podhala, red. S. A. Hodorowicz, Nowy Targ 2004), natomiast słownik Karłowicza z 1911 roku w ogóle nie odnotowuje słowa opartego na formie "ozwaz-" (Słownik gwar polskich, t. 6, red. J. Karłowicz, J. Łoś, Kraków 1911). 
politycznej i ewokuje chociażby sławną broszurę: Czy Polacy moga się wybić na niepodległość??. U autora homilii wygląda to następująco:

Budzom sie narody na Wschodzie. Dopominajom sie o swoje prawo, o swoją godność. Wiater, co idzie bez świat, łómie stare drzewa, a próguje młode. Ka sie ino obrócić, wsędy - co się robi? Niewolnik wybijo sie na obywatela. Dobrze przyjrzyjmy sie tym słowom: niewolnik wybijo sie na obywatela. I tej sprawie dziś sie przyjrzyjmy: tymu wybijaniu sie na obywatela. [...] A razem z tom pieśniom, niek przydzie do nos legenda gór, legenda o ludziach, co z niewolników wybijali sie na obywateli. Legenda o Janosiku, o zołniyrzak, o partyzantak (s. 74).

Powtórzenia dostatecznie wyraźnie sugerują intencję takiego użycia formuły. Połączenie przebiega tu nie tylko na poziomie zestawienia słów (,wybijo sie na obywatela”), ale także polega na przypisaniu pojęcia „obywatel” pewnym postaciom z kręgu historii i mitologii góralskiej. Jeden i drugi zabieg kryje w sobie pewien kontrast, który uderza słuchacza. Gwarowy wariant publicystycznego określenia zachowuje cechę nowości, a może nawet obcości, prowadząc do pytania, czy taka strategia nie jest jednak pewnym nadmiarem. Prawdopodobnie w gwarze dałoby się odnaleźć formę, której można by użyć z większym powodzeniem stylistycznym do p r ze kład u, nie zaś tylko do transformacji wariantatywnej pojęcia. Podobną wymowę ma śmiałe zastosowanie słowa „obywatel” do Janosika, a to dlatego, że „zbójnik” jest semantycznym przeciwieństwem „obywatela”. Trzeba tu jednak uwzględnić fakt, że autor w pojęciu „obywatela" podkreśla konotację dopominania się o swoją godność i prawa. Osobiste poczucie wartości faktycznie może być egzemplifikowane przez Janosika, jednak w dalszym ciągu Tischner wskaże na sprzeczność między wolnością zbójecką a wolnością obywatelską, która polega na równo-

9 J. Pawlikowski, Czy Polacy mogą się wybić na niepodległość?, Paryż 1800. Pojęcie obywatela pojawia się w poezji tak ważnego dla literatury góralskiej i Tischnera Stanisława Nędzy Kubińca: „My nie pachołki już... Obywatele” (S. Nędza Kubiniec, Zielone Święto. Na świętoludowe w Czarnym Dunajcu, w: S. Nędza Kubiniec, Wiersze i poematy, Toruń [1973], s. 17). Jest to jednak wiersz napisany językiem literackim, i to w kontekście politycznym, bo na święto ludowe w Czarnym Dunajcu w 1934 roku. „Obywatel” przynależy zatem do tego społecznego dyskursu wyrażanego w języku ogólnym, ale przecież obejmującego górali w trakcie ważnych przemian. 
ści wobec prawa ${ }^{10} \mathrm{i}$ tu ze względu na zmianę konotacji przykład zbójnika przestaje wystarczać. Konkluzja tej analizy jest taka, że te zbieżności i rozbieżności ujawniają jasną intencję włączenia idei filozoficzno-politycznej we właściwy góralom sposób myślenia, co w sposób oczywisty zachodzi na poziomie języka. Ogólnopolski dyskurs zostaje tu imputowany gwarze, by został zaakceptowany jako własny. I jeśli nawet zabieg ten nie jest w pełni fortunny, to zarazem świadczy o pragnieniu dokonania rzeczy nowej i trudnej, czyli nauczeniu słuchaczy odpowiedzialności za dobro wspólne. Nowe zadanie pogodzenia tego, co lokalne, z tym, co państwowe, znajduje więc refleks w nowości rozwiązań językowych i ideowych ${ }^{11}$.

Zanim jeszcze przyjdzie wskazać na celne propozycje terminologiczne, warto zaznaczyć, że w zapisie uderzają inne formy, które będąc świadectwem pragnienia syntezy dwóch wersji polszczyzny, odbiegają jednak od czystości gwarowej. Na początku jednego z tekstów pojawia się wezwanie: „Rozjesce wsłuchojmy sie w naszom pieśń o ślebodzie” (s. 93). Zaniechanie mazurzenia razi tu na tle całego zdania oraz w pozycji wobec gwarowej końcówki („-om”). Kiedy indziej występuje apel: „Worto dziś przypomnieć” (s. 118), który w gwarze powinien zabrzmieć w postaci: „Worce dziś przybocyć” ${ }^{2}$. Podobnie dzieje się w zdaniu: „A idęcy do samego siebie, do swojego wnętrzo, cłek musi przejść przez zasłony” (s. 127). Quasi-gwarowa forma „wnętrzo” zamiast góralskiego: „do swojego nuku" świadczy zapewne o nazbyt pospiesznym pragnieniu poszerzenia zakresu pojęciowego gwary o słowa łatwo zrozumiałe. Podobna zasada motywuje zastosowanie słowa „jednoceśnie” (s. 135) zamiast regionalnego „wroz”, czy „nojpierw” (s. 109) zamiast „piyrse”. Uwagi te mają wskazać na proces kształtowania się gwary i przysposabiania jej do podejmowania nowych tematów. Oczywiście fortunnych rozwiązań

10 „Bo wolność zbójecko to jest tako wolność, co swobode i ślebode jednego wywyzso ponad drugiego. A wolność państwa musi sie zacynać od równości wobec prawa. Jednakowe prawo dlo syćkik. Jak jo tobie, tak ty mnie. I to sie nazywo państwo obywatelskie. To sie nazywo obywatel" (s. 98).

${ }^{11}$ Należy zauważyć precyzję mówcy, który bardzo umiejętnie wybiera nieliczne terminy („obywatel”, „państwo”) i następnie przedstawia je słuchaczom. Selekcja i dyscyplina stoją na straży zrozumiałego przekazu. (s. 129).

12 A przecieżautor tę formę gdzie indziej stosuje. Por.: „,wolność więcyj worce jako zycie” 
można tu wymienić znacznie więcej. Tischner ciekawie operuje dwoma synonimami, z których „wolność” pochodzi z języka literackiego, a „śleboda” z gwary. Co ciekawe, „wolność” pojawia się w kontekście gwarowym w postaci niezmienionej, po prostu jako słowo powszechnie rozumiane (por. s. 129). Wydaje się, że ten typ mówienia jest stylistycznie lepszy niż niektóre akomodacje gwarowe, trzeba jednak mieć na uwadze fakt żywego przemawiania, które okazuje się trudniejsze od spokojnej redakcji tekstu pisanego.

Jeszcze jeden interesujący sposób wzbogacania gwary i sposobu myślenia polega na zestawieniu kilku słów (congeries) odnoszących się do honoru pojmowanego w kategorii działania zespołowego. Tischner najpierw mówi ogólnie: „Musimy sie tego ucyć [...] przez ucenie w s pól n ot y”. Tu istotne słowo użyte w wersji literackiej zostaje dopełnione synonimem „razym”, zaczerpniętym z żywo stosowanej gwary („Zawse my godali: Musimy być razym") i następnie opatrzone sygnałem-komentarzem gwarowym („straśnie wozne”). W ten sposób kolejny termin filozoficzny jest włączany w zakres regionalnej wersji polszczyzny. W dalszym ciągu tak wyodrębnione słowo otrzymuje wyjaśnienie w postaci dwóch innych, można rzec, jego konotacji: „Ale razym to nie znacy ino kupom. Razym to znacy - w organizacji” (s. 98). Obydwa słowa mówią coś o wspólnocie, przy czym pierwsze, potoczne („kupa”) ma szerszy zakres, ale węższą treść. Punktem docelowym tej argumentacji jest jednak słowo „organizacja", które następnie będzie zestawione z szeregiem konkretnych nazw w ramach distributio. Mówiąc o organizacji nie tylko Związku Podhalan czy partii, ale nawet kółek maszynowych, homileta wyraża ideę uporządkowanego życia społeczności lokalnej. Na poziomie języka odzwierciedla to pragnienie proces wikłania słów ogólnych w konteksty gwarowe: „ucenie wspólnoty”, „razym zorganizowane”. Tak więc i tutaj uwidacznia się potrzeba używania gwary z poszerzeniem jej o inne słowa, ważne z etycznego punktu widzenia. Zostają one przystosowane, niejako oswojone najpierw poprzez nadanie nowych cech fonetycznych („Świat stoi organizacjom”). Z drugiej strony w zestawieniu „kupy” i „organizacji” widać też, że to drugie, zewnętrzne słowo jest ważniejsze, a świadczy to znowu o konieczności rozwoju gwary i warunkowanego nią sposobu myślenia. 
W kontekście zmian, którym podlega gwara, należy też dostrzec autorską świadomość archaizacji pewnych form, które właśnie dlatego stara się objaśnić, jak w wypadku cytatu pieśni Stanisława Nędzy Kubińca:

Pise i śpiywo ta pieśń tak: „Idom casy, za casami rumi lić”. Lić to jest downo góralsko nazwa na dysc, na takom siąpawice we mgle, we wietrze. Takom pluche, co końca nie widać. „Zaświeciła nad holami fakieł wić”. Fakle to z niemieckiego języka wzięte słowo „żagwie”, „pochodnie”. „Jak sie fakły nad graniami jasnym ogniem zaświecom, dolinami z pańskik dworów zorne iskry polecom". Widzicie obroz wolności zbójeckiej (s. 94).

Ten autorski komentarz zawiera w sobie i erudycję filologiczną, i wymiar gwarowy. To właśnie pozostaje znamienne, że dawne słowa objaśniane są za pomocą bardziej współczesnej i zrozumiałej dla słuchaczy gwary. Towarzyszy temu procesowi także odwołanie do doświadczenia słuchaczy, które ma charakter zmysłowy, ale i psychologiczny. W ten sposób troska o zrozumiałość przekazu łączy się z potwierdzeniem aktualności gwary jako języka duszpasterskich rozważań. Paradoksalnie, pomimo dystansu tworzonego przez archaizmy, wartość gwary zostaje więc wzmocniona.

\section{Udane realizacje stylistyczne}

Po zbadaniu różnych sposobów homiletycznej praktyki na pograniczu gwary i języka literackiego warto przedstawić wybitne realizacje stylistyczne w tym zakresie. Stanowią one wymowny argument na rzecz owego retorycznego pogłębienia, zyskanego przez zastosowanie regionalnej wersji języka polskiego.

W mowie noszącej redakcyjny tytuł Droga miłości Tischner podejmuje temat pierwszej miłości poprzez przywołanie góralskiego słowa „zalubienie":

Jest taka chwila w zyciu ludzkim, kie cłek do drugiego cłeka godo: „Ty-eś mój!”, „Ty-eś moja!”. I w takiej chwili ludzie cujom, ze som scęśliwi. I wtedy cały świat mógłby zginąć - a im sie wydaje, jakby byli w niebie. Przyjrzyjmy sie, moi ostomili, tymu piyrsemu ludzkiemu „mój”, „moja”. To jest ludzkie - ale to jest i więkse jako cłek. Góralsko mowa mo na tom kwile takie jedno słowo: zalubieni e. Kie sie cłek zalubi, choćby nie wiem, jaki bogoc był, zdaje mu sie, ze je noubozsy na świecie (s. 104). 
„Zalubienie" jest bardzo trafnym słowem. Rdzeń zawiera w sobie znaczenie „miłowania” wspólny gwarze i staropolszczyźnie. Od strony etymologicznej czasownik „lubić” według Stownika staropolskiego ma następujące znaczenia: a) „znajdować w kimś upodobanie, lubić, kochać kogoś, delectari aliquo" b) lubić się „być miłym, podobać się, gratum esse, placere” c) lubić się „uchodzić za pożądane, za właściwe, wydawać się właściwym, placere, aequum videri” d) lubić c zyją ś duszę „obciążać odpowiedzialnością czyjąś duszę (czy też wzywać do złożenia przysięgi, periculum alicuius rei in alterius conscientiam transferre". Staropolski rzeczownik „lubienie” przyjmuje następujące znaczenia: „przyjaźń, zgoda, porozumienie, amicitia, concordia” ${ }^{13}$. Natomiast czasownik z prefiksem „,za-,,, czyli „zalubić, zalubić się" przedstawia się tu następująco: a) „zawrzeć układ, umowę, foedus inire, pingere" b) „obdarzyć uczuciem, pokochać, amare, diligere” c) zalubić się „zobowiązać się, obiecać, promittere, obligari” ${ }^{14}$. Spotykają się tu ze sobą dwie szczególne grupy konotacyjne - „umiłowania i upodobania” oraz „nawiązania trwałej relacji” zwłaszcza w sensie prawnym, co na podstawie podanych w słowniku przykładów może odnosić się np. do przymierza Boga z Abramem czy do więzi małżeńskiej. Takie translatorskie zastosowanie w odniesieniu do Biblii oznacza, że „zalubić" wyraża ideę najgłębszej miłości wiernej i ma wydźwięk najbardziej pozytywny. Nieco dalej te obydwa znaczenia miłości i trwałości można dostrzec w słowie ,ślub”. Natomiast w zakresie gwary pojawia się pierwsze $\mathrm{z}$ tych znaczeń, tj. „mocna miłość". Według Słownika gwary górali Skalnego Podhala Stanisława Hodorowicza „zalubić” oznacza „pokochać”, zaś „zalubić się" - „zakochać się, obdarzyć uczuciem”"15. W Stowniku gwar polskich Jana Karłowicza „zalubienie” ma znaczenie „kochać się”, a przykład ten pochodzi pierwotnie ze Słownika prowincyonalizmów powiatu będzińskiego Józefa S. Ziemby, co oznacza szersze niż tylko na Podhalu występowanie tego słowa w zakresie gwar ${ }^{16}$.

13 Słownik staropolski, t. 4: L-M, red. nacz. S. Urbańczyk, Wrocław-Warszawa-Kraków 1963-1965, s. 66-67.

14 Słownik staropolski, t. 11: Z-Ż, red. nacz. S. Urbańczyk, Kraków 1995-2002, s. 114.

15 Słownik gwary górali Skalnego Podhala, dz. cyt., s. 301.

16 Stownik gwar polskich, dz. cyt., s. 293. 
Tischner w swoich rozważaniach podejmuje tę konotację jako dominantę znaczeniową. "Zalubienie” oznacza u niego stan totalnego zaangażowania w miłości skierowanej ku konkretnej osobie: „Zalubienie to jest siyła. To jest siyła więkso jako cłek" (s. 105). Świetną ilustracją (exemplum), a w zasadzie obrazową definicją pojęcia, jest obszerny fragment z opowiadania Kazimierza Przerwy-Tetmajera Dziki Juhas, w którym tytułowy bohater, Bronek Luptowski, obdarzony niezwykłą siłą, znalazł na swej drodze przeszkodę, gdy dziewczyna, w której się zakochał, nie odwzajemniła jego uczuć. Stopień zaangażowania oddaje tu powtórzone za autorem Skalnego Podhala określenie: „E, to jest piyknie powiedziane, nie? Jak sie cłek zalubi, to tak jakbyś mu duse wyjon, a inksom wraził" (s. 105). W połączeniu z finałem przytoczonego opowiadania, w którym Bronek z wściekłości zabija swoje owce oraz z fragmentem pieśni góralskiej („Еj, ni mom nic, ni mom nic | i o nic nie stoje. | Ej, ino to, co kochom, | coby było moje") ukazuje się tu znaczenie miłości pojmowanej jako ostateczny i najważniejszy wybór. Tak właśnie homileta przedstawia tę kwestię: „Nojpierw jest zalubienie, a końcym - wybranie” (s. 109). Ta właśnie relacja wybrania obdarowana jest zresztą drugą z konotacji „zalubienia”, czyli przysięgą, gdy bowiem Agnieszka Hawrańcówna odmawia uczuć Bronkowi, czyni to z powodu tak ukształtowanego wyboru: „Bok ślubowała Jędrzkowi Hawrańcowi" (s. 106).

W ten sposób widać, jak głęboko pojęcie „zalubienia” wyraża ideę miłości wiernej. Homileta na tej podstawie zestawia odważnie to gwarowe ujęcie z tekstami biblijnymi, odnajdując analogię między nimi. Ważne są tu zwłaszcza słowa z Pieśni nad pieśniami: „Bo mocna jest jak śmierć miłość, twarda jak otchłań jest zazdrość. Pochodnie jej - pochodnie ognia i płomieni. Wody mnogie nie mogły ugasić miłości i rzeki nie zatopią jej. Choćby człowiek dał wszystką majętność domu swego za miłość, wzgardzi nią jako nicością" (Pnp 8, 6-7; s. 108). Pojawiają się tu jako cechy wspólne zarówno pełne osobiste zaangażowanie, jak i motyw sensowności oddania wszystkiego za miłość. Pojęcie z zakresu kultury ludowej i gwary ukazuje tu swoją wielką zbieżność z natchnionym poematem o miłości i dzięki temu proces inkulturacji odbywa się z większą jeszcze głębią.

W dalszym ciągu Tischner przytacza w tym kontekście także Augustyńską zasadę, nadając jej formę gwarową: „Cłeku, kochoj i rób, co fces” (s. 109). 
Przyznać można, że lapidarność tego adagium została oddana w niepozbawionej dosadności wersji polszczyzny, bowiem w kulturze góralskiej występują często podobne, zwięzłe wypowiedzi, kryjące w sobie ludową mądrość, będącą niekiedy źródłem humoru. Ważniejsze jest jednak to, że starochrześcijańska zasada otwiera przestrzeń wolności, która wynika z miłości. Związek tych postaw, niezwykle ważnych dla etosu góralskiego, polski mówca wydobywa za pomocą komentarzy, które pięknie oddają zwięzły ton gwary: „Jak bees kochoł, to bees wiedzioł, jakie jest prawo. Wsłuchoj sie w to prawo miłości, a bees wiedzioł, co robić. Starym powiedziano tak: «Nie bees zabijoł». Ale fto sie wsłucho w prawo miłości, ten nie ino nie zabije, ale som zginie za swojom miłość" (s. 109). Analizowany powyżej przykład „zalubienia” wskazuje na możliwości odkrywania związków pomiędzy dziedziną gwary a wiarą głoszoną na podstawie objawienia i wykorzystywania ich w praktyce. Wzmocniony, naddany kontakt zyskuje tu znaczące dopełnienie na poziomie referencyjnym, znaczeniowym, gdy słowo z tak bliskiego słuchaczom zakresu może przywoływać ten sam desygnat co język biblijny. Aby tak się stało, potrzebna jest dyskretna i umiejętna praca mówcy.

W homiliach spod Turbacza można odnaleźć podobne, interesujące z punktu widzenia retorycznego rozwiązania, które są świadectwem udanego połączenia kultury literackiej z gwarą. Przykładem może być alegoria góry zastosowana dla perswazji:

Widzicie, w zyciu to jest tak: „Gdzie jest dwóch abo trzech w imię moje, tam Jo
jestym między wami”. Jest nos dwók abo trzek, i jest Ftosi między nami, co patrzy
na nos z góry. Ten, co patrzy z góry, widzi jednom strone, widzi drugom strone.
Jo widzem ino siebie, ty widzis ino siebie. Ale Tyn, co jest pomiędzy nami, patrzy
z góry i widzi mojom prowde, widzi twojom prowde - i wtedy całość wychodzi
mu troche inacyj. I w sprawie tej góralskiej partyzantki - po wojnie i w casie woj-
ny - wciąz jesce tak jest, ze tego trzeciego widoku, tego widoku z góry, ni mozna
sie dorobić (s. 130).

Zgodnie z zasadą tworzenia alegorii z pojęcia góry została tu wyodrębniona dominanta znaczeniowa, którą stanowi różność perspektyw poznawczych wyznaczanych przez górę, gdy widok z wierzchu odznacza się pełnią, a te z dołu pozostają cząstkowe. Sam dobór motywu jest znaczący, ponieważ Tischner zwraca się do „ludzi gór”, a homilia głoszo- 
na jest na górze Turbacz. Mówca apeluje zatem do doświadczenia szczególnie bliskiego. Ten układ przestrzenno-poznawczy góry każdy ze słuchaczy może sobie nie tylko łatwo wyobrazić, ale wręcz zobaczyć. Cała struktura zostaje tu zestawiona z cytatem z Ewangelii (por. Mt 18, 20) w ten sposób, że alegoria góry stanowi ro zw in ięc i e tekstu natchnionego i jego komentarz. W wersecie biblijnym nie ma mowy o tym, że Bóg obecny jest w górze, już raczej pojawia się sugestia tego samego poziomu przebywania. Tymczasem alegoria wprowadza zróżnicowanie oparte zresztą na mocno utrwalonym obrazie Boga, który wznosi się ponad światem. W tym kontekście ta obecność wertykalna podkreśla wszechwiedzę i pełnię Boskiego poznania. Wobec niej wiedza człowieka jest częściowa, dlatego zostaje nacechowana znaczącym zaimkiem dzierżawczym „moja”, „twoja” „prowda”. Na podstawie alegorii nie można tu dopuścić rozumienia relatywizującego prawdę, ponieważ każda częściowa prawda oznacza udział w czymś substancjalnie jednym. Po takim alegorycznym opisie przestrzeni pojawia się domyślny postulat ostrożnego formułowania sądu, który zostaje aplikowany do konkretnej sprawy, tj. góralskiej partyzantki, ale w szerszej perspektywie służy zwróceniu uwagi na szacunek dla adwersarza, czyli na uszanowanie w przeciwniku jego „honoru”.

Językowa wrażliwość Tischnera objawia się w wielu drobnych realizacjach stylistycznych. Na przykład modyfikuje on znaczenie słowa „zaprzaniec" o tyle, że odwraca oczekiwany desygnat. Słowo oznaczające kogoś, kto dopuszcza się zdrady, tutaj zostaje odniesione do bohaterów narodowych w ten sposób, że podkreśla ich decyzję zaparcia się swojego życia dla wyższej sprawy. Ta ewokująca Ewangelię (por. Łk 9,23) ocena tym mocniej podkreśla znaczenie patriotyzmu (por. s. 86-87). Kiedy indziej temat psucia państwa mówca ilustruje celną, krótką alegorią: „I kozdy z nos, jako umioł, jako potrafił, to przykładoł swoje klyscyki do tego, zeby to państwo obce ozmontować, zeby go jako zepsuć" (s. 97). Dzięki temu działanie zostaje przedstawione w sposób konkretny i dosadny, jak to zostało już ukazane - właściwy gwarze, ale także językowi biblijnemu (parabole). Nie tylko jednak Ewangelia stanowi punkt odniesienia dla językowych nawiązań. Kiedy indziej będzie to nawet... komunistyczny slogan. Zdanie „Widmo śmierci krązy nad sercami” (s. 85) jest trawe- 
stacją zdania „Widmo krąży po Europie - widmo komunizmu”, otwierającego Manifest komunistyczny Karola Marksa. Jeśli nawet nawiązanie to nie wynika z intencjonalnego działania, to przecież pozwala pośrednio zestawić „śmierć” na wojnie z doświadczeniem komunizmu i w ten sposób pogłębić percepcję historii.

\section{Kultura góralska miejscem wspólnym}

Fakt, że kultura góralska i gwara stanowią ów pogłębiony kod, wpisany w liturgię, znajduje swoje odzwierciedlenie w kwestii topiki, czyli miejs c ws pólny ch, do których mówca odwołuje się jako do warunku porozumienia i perswazji. Idąc tym tropem, można w homiliach spod Turbacza śledzić przywołania tekstów z zakresu wiary oraz kultury ludowej. Szczególnie interesująca będzie obserwacja zasady cytowania oraz ich wzajemnego połączenia w jednej linii myślenia i argumentacji. Tischner jako kapłan sięga do słowa Bożego czytanego w trakcie mszy, przy czym nie podejmuje szerszej egzegezy biblijnej. Z całości tekstów przywołuje staranie wybrane logiony, które stanowią punkt wyjścia do rozważania. Selekcja poprzez ograniczenie ilościowe pozwala na lepszą koncentrację na wybranym fragmencie, by mógł zostać dopełniony komentarzem, w którym dużą rolę odgrywają elementy góralskie wraz z odwołaniami do historii i współczesności. W mowie z 1989 roku motywem biblijnym są słowa: „Panie, pokoz mi dróge, ftorom trza mi iść, bo duse wznoszę ku Tobie" (Ps 143, 8; s. 73). Już samo ich ujęcie i powtarzanie w wersji gwarowej świadczy o intencjonalnym zbliżeniu tych dwóch dziedzin. Prośbę o wskazanie drogi autor łączy z przemianami roku 1989, które dotyczą rzeczywistości zarówno społecznej, jak i indywidualnej. Właśnie konieczność przejścia od czysto osobistych interesów do wspólnotowego działania stanowi przedmiot argumentacji i jednocześnie kontekst interpretujący biblijny werset. W tej linii pojawia się jako argument z przykładu (exemplum) scena z opowiadania Za sytko Kazimierza Przerwy-Tetmajera, w której bohater doznaje takiej przemiany na widok powstańców chochołowskich. Linia rozumowania przebiega w pewnym momencie następująco: po refrenicznym powtórzeniu wersetu padają słowa: „Jest, bracia 
i siostry, tako godzina w zyciu cłeka, we ftorej ukazuje mu sie - tak jasno, jak słonko na niebie! - ze go Bóg nie stworzył na niewolnika, ba wolnym. Pisoł o tym prowdziwie Kazimierz Przerwa-Tetmajer" (s. 75). Celne zdanie nawiązania wydobywa dominantę znaczeniową i stanowi pomost między obydwoma tekstami, kulturowo i stylistycznie odległymi od siebie. Praca mówcy zmierza nie tylko do pokonania tych różnic, ale do odnalezienia ich wspólnego rdzenia, którym tutaj jest doświadczenie wolności. Z kolei tekst gwarowy stanowi szczególnie ważny argument, bowiem przynależąc do kanonu góralszczyzny, ma autorytet w oczach zgromadzonych. Oczywiście rzeczą podstawową jest tu fakt, że Tetmajer pisze „prowdziwie”, ale przecież idea pozostaje ściśle zespolona z gwarą jako swoim językiem. Nieprzypadkowo Tischner sięga przecież po ten właśnie tekst ${ }^{17}$, choć podobne ujęcie wolności mógłby znaleźć gdzie indziej. Wersja Tetmajera odznacza się jednak wyjątkowym, artystycznym opracowaniem gwary np. poprzez świetną, zwięzłą, paraleliczną narrację (por. s. 75-76) i dlatego tym lepiej służy całości przedsięwzięcia. Warto również zwrócić uwagę na fakt, że rozwinięciem sapiencjalnego wersetu, który zbliża się do sentencji, jest obszerna narracja, tak więc poprzez autorskie połączenie tekstów i wcześniejszą inwencyjną pracę łączą się z sobą dwie różne genologicznie jednostki.

W funkcji przykładu występuje jednak także poezja. Autorem szczególnie ważnym dla Tischnera jest Stanisław Nędza Kubiniec, z którego bogatej twórczości ${ }^{18}$ cytuje w całości pieśń Idom casy za casami jako ilustrację wolności zbójeckiej. Pieśń ta zawiera niezwykle ważny w całości rozważań wyraz ludzkiego doświadczenia, tj. pragnienia wolności. Ta niezwykle istotna potrzeba zostaje tu wyartykułowana także w kontekście stosunkowo młodej historii, czyli pięćdziesiątej rocznicy pacyfikacji

17 Rolę elementów gwarowych należy za autorem widzieć w szerszym kontekście kultury chłopskiej. Tischner kiedy indziej cytuje wspomnienia Wincentego Witosa (s. 119-120) czy też przypomina historię Stronnictwa Ludowego (s. 117). Opowiada się zresztą za szerokim rozumieniem przynależności do kręgu podhalańskiego (s. 132).

18 Wybór tej pieśni, uzasadniony względami merytorycznymi, warto jednak zobaczyć jako gest inwencyjny na tle innych wierszy Kubińca, wśród których jest także poemat Lenin w Poroninie (S. Nędza Kubiniec, Wiersze..., dz. cyt., s. 287-303). Poeta z Kościeliska był jednak konsekwentnym piewcą chłopskiego wyswobodzenia. 
Waksmunda, bowiem wspomnienie wojny ewokuje tęsknotę za ślebodą. Zaktualizowana w homilii pieśń łączy starą góralską tradycję z nowszą historią oraz z teraźniejszością. Słuchacze zgromadzeni pod Turbaczem mogą i powinni poczuć się uczestnikami tego samego procesu wolności:

„....Po ślebode, syćkim ludziom scęście wić”. Co tu, moi kochani, widzimy? Widzimy ślebode i scęście. Jak ni ma ślebody, ni ma scęścio. Ale biada tymu, co ze ślebody niescęście dlo cłeka przysposobi. Trza tak robić z tom wolnościom, coby ze ślebody brało sie ludzkie scęście. I w tej zbójeckiej legendzie jest taki sen, takie marzenie - o tej wolności, co z góry przyjdzie, wyrówno świat i kozdemu cłowiekowi scęście przyniesie. [...] Ale zbójecko śleboda niepewno (s. 95).

Należy zauważyć, że tekst Nędzy Kubińca, traktowany z atencją, zostaje jednak poddany interpretacji ze strony mówcy. Potrzebę takiego dopełnienia generuje fakt, że przedstawiona w pieśni wolność zbójecka nie jest jeszcze pełną formą wolności, a do takiej mówca pragnie przekonać. Tischner pozostawia sygnały wskazujące na owo w i ę c e j, które chciałby wnieść. Jest to na przykład w powyższym tekście określenie ślebody zbójeckiej mianem „niepewno”, co otwiera kolejny etap rozważań. Pojawi się w nim koncepcja wolności zbudowanej na prawie, która w przeciwieństwie do zbójeckiej uwzględnia uprawnienia i potrzeby drugiego człowieka. Mówca wyrazi się nawet następująco: „...jest sprzycność pomiędzy wolnościom zbójeckom a wolnościom prawa" (s. 97). Autentyczne pragnienie wolności dla siebie, charakterystyczne dla tradycji zbójnickiej, powinno zostać dopełnione wolnością prawa, którą Tischner czerpie od Jana Pawła $\mathrm{II}^{19}$. Autorytet góralskiej pieśni zostaje zatem poddany interpretacji filozoficznej i kościelnej. Odwrotnie niż we wcześniejszym układzie, tym razem to nie tekst gwarowy objaśnia religijny, ale sam podlega stosownej ocenie i dopełnieniu.

19 Odwołania do Jana Pawła II pojawiają się w tych kilku homiliach częściej. Pokutny gest papieża przepraszającego w czasie pielgrzymki do Czech i Słowacji protestantów za historyczne krzywdy staje się punktem wyjścia do apelu o porozumienie w Polsce. Towarzyszy temu argument w postaci pytania-comparatio, czy ojciec święty nie będzie musiał przepraszać za polskie grzechy (s. 121). Na innym miejscu postać Jana Pawła II jawi się w specyficznym kontekście góralskim, ponieważ Tischner przypomina skierowaną do niego samego, i to zaledwie wczoraj, wypowiedź namiestnika rzymskiego: „Chodzicie moimi drogami” (s. 103), a następnie gest ucałowania przez niego polskiej ziemi. Służy to sformułowaniu zaproszenia do dotknięcia i swoistej kontemplacji rodzinnej ziemi w kontekście miłości. 
W obszarze gwary szczególnym miejscem wspólnym jest pieśń góralska w wersji ludowej. Tischner regularnie odwołuje się do niej, traktując ją jako skarbnicę ważnych myśli i zapis ludzkiego doświadczenia, które nosi cechy ponadczasowe i dlatego może być przedstawiane słuchaczom. $\mathrm{Z}$ upodobaniem sięga też do tych samych tekstów ${ }^{20}$, na przykład do śpiewki:

Zatonie, zatonie

piórecko na wodzie,

ale nie zatonie

nuta o ślebodzie (s. 80, 83, 93, 123).

Poprzez te repetycje w różnych tekstach znaczenie topiczne pieśni zostaje mocniej wyeksponowane. Również sam autor pozostawia sygnały wagi tej anonimowej twórczości, gdy stwierdza: „....trza nom usłyseć głos serca. Rozumiycie? U s ły s e ć. Ale jak? Ka go usłyseć mozes? Nei kazby, jak nie w góralskiej pieśni” (s. 84) i dodaje, że głos serca jest zaklęty w góralskiej muzyce (s. 85). Mówi także w formie metatematycznej uwagi: „I tak w nucie wraco sie to, co w cłeku siedzi" (s. 110). Przemawiając o miłości, zwraca uwagę, że w pieśni góralskiej o miłości śpiewa się tak, jakby się śpiewało o samym Bogu (s. 108), co oznacza wyjątkową jej przydatność jako rejestru doświadczenia w konstruowaniu mowy. Jeszcze szerzej na tę funkcję wskazuje w innej wypowiedzi, podejmującej problem obecności pieśni góralskiej w liturgii: „A niejedyn moze sie spyto, cymu to teroz, na Mszy Świętej, my tom nute przybacujemy. Odpowiedźjest prosto: ta pieśń jest to pieśń o miłości. [...] A jak nie zrozumies, co to znacy w zyciu miłość, to nie pojmies tyk słow, ftore były tez i w dzisiejsej Ewangelii powiedziane, ze «Bóg jest Miłościom» (s. 128) ${ }^{21}$. Nuta zawiera w sobie zatem ludzkie doświadczenie, które stanowi przygotowanie do przyjęcia słowa Bożego i w ten sposób formacja ludzka spotyka się tu z kształtowaniem duchowości religijnej. Podsumowując, można powiedzieć, że w zakesie inwencji toposy teologiczne i regionalne łączą się ze sobą w różnych konfiguracjach, służąc perswazyjnym celom.

20 Tischner zwraca przy tym uwagę nie tylko na walory tekstu, ale także samej muzyki: "Słowa słowami, ale melodia, ale nuta - jak ten wiater, co dziś pomiędzy nami duje” (s. 108).

21 Gwoli ścisłości zdanie „Bóg jest Miłością” pochodzi z 1 J 4, 8. 


\section{Podsumowanie}

W okolicznościowych homiliach głoszonych pod Turbaczem ks. Tischner podejmuje zadanie wykorzystania gwary góralskiej i kultury ludowej Podhala, przypisując im ważne funkcje. Gwara stanowi tutaj pogłębiony kanał i kod komunikacji, gdyż ustanawia dodatkową więź między mówcą a słuchaczami, co następnie służy celom perswazyjnym. Świadomość tej szczególnej relacji pozwala łatwiej apelować o zajęcie konkretnych postaw. Sprzyja temu także stosowanie czasowników w trybie rozkazującym, wyposażonych w cechę dosadnego, konkretnego doświadczenia. W budowanie przestrzeni porozumienia wpisane jest także zaproszenie do specyficznej medytacji na fundamencie głoszonego słowa. Tischner dokonuje tu próby połączenia terminologii i rzeczywistości religijno-duchowej z nazewnictwem gwarowym i ludową postawą ,zadumania”. Te usiłowania idą jednak znacznie dalej i dotyczą przeniesienia na płaszczyznę gwary i góralskiego sposobu myślenia idei zaczerpniętych z dyskursu polityczno-społecznego („obywatel”, „organizacja”), co daje interesujące rezultaty i odzwierciedla oczywiste z punktu widzenia ideowego znaczenie takich zabiegów. Perswazja polega tu na medytacyjnym kształtowaniu myślenia odbiorców. O wadze tego procesu świadczą nawet pewne rozwiązania, które z punktu widzenia językowego mogą jawić się jako dyskusyjne.

W tekstach uderzają jednak udane rozwiązania stylistyczne, które stanowią narzędzie homiletycznego procesu. Szczególnym przykładem jest wykorzystanie mocno zakorzenionego w gwarze słowa ,zalubienie”. Autor najpierw mocno je eksponuje, zarówno poprzez wskazanie na cechy znaczeniowe, jak również obszerny przykład z opowiadania Przerwy-Tetmajera. Wydobyta w ten sposób idea miłości angażującej totalnie jako ostateczny wybór osoby przez osobę zostaje odniesiona do tekstów biblijnych, by to znaczenie przedstawić w najwyższym rejestrze i w relacji do samego Boga. Następnie kontekst myśli św. Augustyna pozwala rozwinąć tę ideę poprzez znaczenie miłości będącej źródłem i miarą wolnego działania. Kiedy indziej zastosowanie alegorii góry z cechą wertykalnego odróżnienia w funkcji komentarza do słów Chrystusa przedstawia Jego obecność wśród ludzi z podkreśleniem Jego Boskiej wiedzy, przewyższającej ludz- 
kie myślenie, co następnie służy sformułowaniu apelu o powstrzymanie się od niewłaściwych ocen i szacunek dla adwersarzy. Te i inne przykłady dowodzą, jak fortunnie autor homilii potrafił łączyć rozmaite elementy w kształtowaniu postaw wiernych.

W trakcie lektury bardzo wyraźnie ujawnia się też idea potraktowania tekstów góralskich jako mi ejsc ws pólny ch. Mogą pojawić się one w funkcji literackiego komentarza do rozważanej biblijnej wypowiedzi. Z drugiej strony, zwłaszcza w pieśni ludowej, stanowią one zapis ludzkiego, uniwersalnego doświadczenia. Jego aktualizacja poprzez cytat pozostaje otwarta na stosowną korektę z punktu widzenia wiary, ale ważniejsze jest tutaj ewokowanie tego, co w człowieku dobre i szlachetne, ponieważ stanowi ono warunek wyższego doświadczenia. Na tej zasadzie wskazanie na ludzką miłość otwiera drzwi do poznania Boga, który jest Miłością. 


\section{Summary}

Rola elementów regionalnych w wybranych homiliach księdza Józefa Tischnera

W swoich homiliach głoszonych pod Turbaczem ks. Józef Tischner wielostronnie wykorzystuje potencjał gwary i kultury góralskiej w procesie duszpasterskiej perswazji przyjmującym formę medytacyjnego oddziaływania. Elementy regionalne tworzą pogłębiony kod komunikacji, w który zostają włączone wątki ogólnego, bardziej powszechnego duskursu ideowego. Fortunne rozwiązania, zwłaszcza wkomponowanie pojęć regionalnych jako miejsc wspólnych niosących w sobie zapis doświadczenia w kontekst nauki chrześcijańskiej, służą dojrzałemu kształtowaniu postaw wiernych. Osiągnięcia Tischnera pozostają ważnym punktem odniesienia w dyskusji o inkulturacji Ewangelii.

Słowa kluczowe: homilia, gwara i kultura góralska, perswazja, miłość, wspólnota, miejsce wspólne

The Role of Regional Elements in the Selected Homilies by Józef Tischner

Jozef Tischner, a Polish famous priest, in his homilies performed on Turbacz moutain employs the potency of Polish highlander's dialect and culture. The various aspects of his work constitute the process of pastoral persuasion in its meditative form. Regional elements mean the priviledged area of communication of the preacher and the faithful to which some threads of general ideas are linked. The accurate achievements-among which the inputting of regional elements as containing human experience (loci communes) into the context of Christian teaching arises-serve homiletical aims. These Tischner's orations are an important point of reference in a discours on 'inculturation' of the Good News.

Keywords: homily, Polish highlander's dialect and culture, persuasion, love, community, locus communis

\section{Bibliografia}

Dziwisz S., Pro memoria o tzw. Mszach Św.,,w góralskiej oprawie”, ,Biuletyn Duszpasterski” 12 (2005), s. 11-12.

Godawa M., Bogomyślność. Zagadnienie zjednoczenia człowieka z Bogiem w medytacji na podstawie „Fascykułu nabożeństwa różnego” Adama Opatowiusza, Kraków 2006.

Nędza Kubiniec S., Wiersze i poematy, Toruń [1973]. 


\section{Marcin Godawa}

Nowy Testament w przekładzie Marii Matejowej Torbiarz na gwarę górali skalnopodhalańskich z Zakopanego, red. M. Przybył, Zakopane 2005.

Pawlikowski J., Czy Polacy mogą się wybić na niepodległość?, Paryż 1800.

Słownik gwar polskich, t. 6, red. J. Karłowicz, J. Łoś, Kraków 1911.

Słownik gwary górali Skalnego Podhala, red. S. A. Hodorowicz, Nowy Targ 2004.

Słownik staropolski, t. 4 L-M, red. nacz. S. Urbańczyk, Wrocław-Warszawa-Kraków 1963-1965.

Słownik staropolski, t. 11 Z-Ż, red. nacz. S. Urbańczyk, Kraków 1995-2002.

Tischner J., Słowo o ślebodzie. Kazania spod Turbacza 1981-1997, oprac. K. Tischner, posłowie W. Bonowicz, Kraków 2003. 